\title{
Flood management in urban Senegal: an actor-oriented perspective on national and
} transnational adaptation interventions

\author{
Schaer, Caroline; Thiam, Mame Demba ; Nygaard, Ivan
}

Published in:

Climate and Development

Link to article, DOI:

10.1080/17565529.2017.1291405

Publication date:

2018

Document Version

Peer reviewed version

Link back to DTU Orbit

Citation (APA):

Schaer, C., Thiam, M. D., \& Nygaard, I. (2018). Flood management in urban Senegal: an actor-oriented perspective on national and transnational adaptation interventions. Climate and Development, 10(3), 243-258. https://doi.org/10.1080/17565529.2017.1291405

\section{General rights}

Copyright and moral rights for the publications made accessible in the public portal are retained by the authors and/or other copyright owners and it is a condition of accessing publications that users recognise and abide by the legal requirements associated with these rights.

- Users may download and print one copy of any publication from the public portal for the purpose of private study or research.

- You may not further distribute the material or use it for any profit-making activity or commercial gain

- You may freely distribute the URL identifying the publication in the public portal 


\title{
Flood management in urban Senegal: an actor-oriented perspective
}

\section{on national and transnational adaptation interventions}

\author{
By Caroline Schaer (UDP), Mame Demba Thiam (IFAN), Ivan Nygaard (UDP) \\ Post print version of paper published in
}

Climate and Development, Vol. 10, No. 3, 2018, p. 243-258

www.tandfonline.com/doi/full/10.1080/17565529.2017.1291405

\begin{abstract}
In Senegal, considerable development assistance has been allocated to addressing the problem of repeated flooding in urban areas, involving changing thematic objectives, from short-term disaster relief to wide-ranging sanitation and drainage programmes. In spite of these numerous flood management interventions, the number of flood victims in Senegal's urban centres has increased steadily since 1999. This article contributes empirically and conceptually to recent studies highlighting poor national disaster risk-management frameworks in West Africa, by investigating how floods have been managed in Senegal and why this management has not led to the results expected by the population. The article finds that the configuration of flood management policies and programmes in urban Senegal points towards three key intertwined issues which have influenced the limited achievements of flood management in urban areas. These include, but are not restricted to, the political and personal appropriation of flood management-related processes, the reinforcement of the dichotomy between central government and municipalities, and a fragmented institutional framework with overlapping institutions.
\end{abstract}

KEYWORDS: Disaster risk management, climate change adaptation, actor-oriented approach, planned interventions, flood management policies, peri-urban areas, Senegal.

\section{Introduction}

Since 1999, seasonal floods have become prevalent to the extent that the rainy season has been renamed the flooding season by the residents of poor peri-urban areas on the outskirts of Dakar, Senegal. This situation is characteristic of many countries in West Africa, where entire neighbourhoods on the outskirts of cities are almost annually paralyzed by massive flooding, a situation which is due to uncontrolled urban growth, poor urban planning and inadequate stormwater drainage systems, and which is expected to be exacerbated by climate change (World Bank and GFDRR, 2011). Evidence from the region suggests a situation of ineffective national responses with respect to disaster risk management and responses to flooding (Rakhi et al., 2008). Although governmental authorities are usually expected to assume full responsibility for disasters and individual safety (Paton and Johnston, 2004), there is an emerging perception that they cannot avert all disasters or protect people from all of their consequences (Maguire and Hagan, 2007), especially in developing countries where numerous actors are involved in disaster risk management because of limited financial resources, technical expertise and/or technological capabilities,. Disaster risk management is part of Senegal's Poverty Reduction Strategy, and the country is a signatory to the Hyogo Framework for Action (HFA), which until recently has constituted the overarching international policy framework that has brought governments, international development agencies, experts and NGOs into a common system of coordination to reduce disaster risks and increase resilience to hazards. It was replaced in March 2015 by the Sendai 
Framework for Disaster Risk Reduction (2015-2030). In contrast to many other West African countries, flood mitigation and adaptation initiatives in Senegal have multiplied over the last fifteen years, being led by the government with support from bilateral and multilateral donor agencies and NGOs. However, in spite of considerable donor and government funding allocated to addressing the problem of seasonal flooding in urban areas, few sustainable solutions have been proposed thus far. Instead, the number of flood victims in Senegal's urban centres increased steadily from 170,000 in 1999 to 900,000 in 2009 (Senegal, 2010). Most of these victims live in peri-urban areas at the periphery of Dakar (Pikine and Guédiawaye, see map 1), which are characterized by slums and inadequate critical infrastructure and state services, such as waste management, sanitation and water (Diouf, 2009). The last fifteen years, floods have recurred almost yearly in these zones with varying durations and impacts, such as the disruption of income generating activities, family fragmentation, death, negative health impacts (such as diarrheal disease, wound infections and Malaria) and the destruction of houses and infrastructure (Schaer and Hahonou, forthcoming). As a result, inhabitants who are mainly un- or underemployed, see their already significant vulnerability severely increased for every new flood event. They are repeatedly forced to apply short term strategies to cope with, and adapt to this situation, which are often maladaptive and thus make them even more vulnerable to future flood events in the long term (Schaer 2015). The underlying causes of urban flooding in the peri-urban areas outside Dakar are complex and consist of a combination of natural as well as human factors (Mbow et al. 2008), including uncontrolled urban growth ${ }^{1}$, which reduced the permeability of ground surfaces and increased run-off rates, the increase in rainfall, non-existent rainwater drainage and rising groundwater levels.

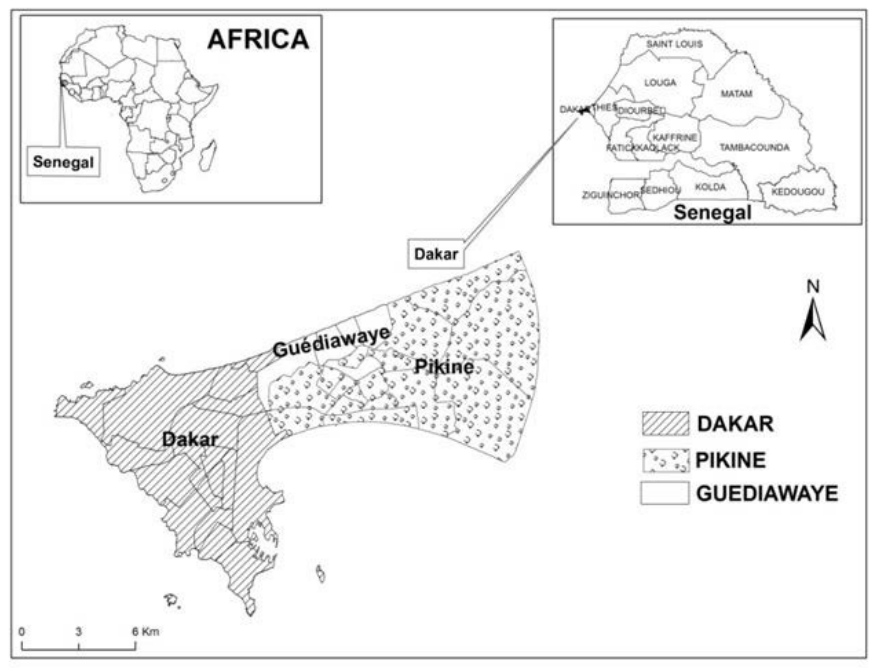

Map 1. Location of peri-urban areas of Dakar: Guédiawaye and Pikine, source: author

The presence of many donors and international aid agencies in the country and the abundance of funds allocated to flood responses have created complex national flood management processes attracting a wide array of competing actors and institutions. These are directly and indirectly

\footnotetext{
${ }^{1}$ Uncontrolled urbanization was a result of an administrative decision to evict residents of Dakar city centre's irregular neighbourhoods (Thoré, 1962) and extensive and uncontrolled rural-urban migration, resulting from extensive droughts of the 1970s, when, because of deteriorating climate and soil conditions for agriculture, rural populations were forced to pursue alternative livelihoods (Fall et al. 2005). As urban sprawl grew beyond the control of the authorities, poor populations had no other alternative than to settle in hazard-prone lowlands.
} 
involved in flood related interventions through a multitude of diverse projects and programmes aimed at flood risk reduction, disaster relief, recovery and long-term climate adaptation.

Analysis of national disaster risk management in West Africa has mainly been driven by multilateral and bilateral aid agencies. In Senegal, numerous analyses of the causes, impacts, needs and costs of flooding have been undertaken over the last seven years by both bilateral and multilateral agencies (GFDRR et al., 2014; UNISDR, 2013; Government of Senegal and World Bank, 2013; UNESCO, 2011; World Bank and GFDRR, 2011; Government of Senegal, World Bank et al., 2010; World Bank and IAGU, 2009; UNISDR et al., 2008). A number of these reports typically identify 'gaps' in the flood management policies that are being pursued nationally, also recommending actions to remedy the current failures to address the problem of recurrent flooding. However, due to their objectives of proposing new actions and interventions, they generally do not go into much detail in seeking to understand the underlying constructed and negotiated currents of influence over the configuration of flood management interventions in the country.

There is a body of academic literature addressing weak institutions and failures in disaster risk reduction (DRR) and climate change adaptation (CAA) governance in developing countries (Agrawal et al., 2008; Adger, 2000; Fatti and Patel, 2013; Lindell, 2008; Yaro et al., 2014; Kern and Alber, 2009; Satterthwaite, 2011). There is another body of literature scrutinizing the practices behind the flood management approaches adopted in the West African region (see Bang, 2014; Thiam, 2013; Thiam, 2011, Diagne and Ndiaye, 2009), as well as some research analysing the implications of decentralisation for public service delivery in Senegal (Resnick, 2014a; Resnick, 2014b), but there has so far been no research which critically investigates the interplay between various development actors and state institutions, or which tries to understand how this interplay shapes institutions, policies and outcomes in relation to flood management.

To contribute to filling this research gap, this article aims to answer the following research questions: How have urban floods been managed in Senegal and why has this management not led to the results expected by the population?

The analytical framework is outlined in section 2, followed by the methodology adopted in section 3. A chronological empirical account of the flood management policies and interventions adopted is outlined in section 4, followed by a discussion of the unintended consequences of this configuration in section 5 . A brief conclusion is provided in section 6 . 


\section{Analytical framework}

\subsection{Conceptualizing flood management interventions}

The approach followed in this article departs from the view of the state as a unified source of intentions, policies and coherent plans: instead the state is viewed as a set of complex social and negotiating processes among various actors and groups (Blundo and Le Meur, 2009), where donor interventions play a preponderant and overlapping role in state interventions. This perspective is based on elements from the anthropology of public spaces and the public action literature (Olivier de Sardan 2008; Lund 2007; Migdal 2001; Migdal and Schlichte 2005; Blundo and Le Meur 2009), which considers both public policy interventions and interventions by development institutions as the same object of study. These interventions are today intertwined to the extent that a separation line between external aid and 'endogenous' resources is now seen as futile (Bierschenk and de Sardan, 2014). As a result, the term 'intervention' is used here as an umbrella term encompassing projects and programmes engaged by, and involving, both government and development institutions (bilateral and multilateral aid agencies and NGOs). The article adopts a broad approach to flood management interventions in Senegal. These include programmes and projects of diverse scope (from food aid distribution in a flooded neighbourhood to the development of drainage master plans) and at different temporal scales of a flood event, ranging from hazard mitigation and preparedness (i.e. early-warning systems), via acute relief (i.e. shelter and food aid), community recovery and reconstruction (i.e. new housing and drainage systems) to long-term climate adaptation (i.e. development of sanitation systems and municipal capacity building).

\subsection{Flood management interventions as arenas for struggle and negotiated processes}

Since public authority is no longer considered to be solely the capacity of the state and is exercised and influenced by diverse actors, including donors, it may take many different forms, which may sometimes function in agreement and sometimes in competition or direct conflict (Lund, 2006). External aid is thereby mediated and modelled differently by these actors and the structures in which they operate (Long, 2001). Central to this line of thought is a critical view of the linear and rational thinking behind the ideal-type donor intervention, exemplified by the logical framework approach, according to which problems can be identified, followed by appropriate actions, leading in turn to predictable outcomes (Mosse, 2004). Instead, consistent with the actor-oriented perspective applied here, development interventions are regarded as being part of ongoing socially constructed and negotiated processes (Long and Ploeg, 1989), where actors exercise various forms of influence and hold diverging interests and conflicting motives (Bierschenk, 1988), and where the unintended consequences are often more important than the intended ones (Ferguson, 1994). A central element to the analytical framework applied here is therefore the assumption that the constant social and political struggles that occur between actors involved in interventions create new arenas for struggle over issues, resources, values and representations (Olivier de Sardan, 2005). In this article, arenas are therefore considered to be places of confrontation between actors over a 
shared issue, where they mobilise social relations and deploy diverse methods to obtain specific ends. Arenas do not thereby necessarily occur in distinctly demarcated settings, but may take place at different temporal scales and may therefore emerge between geographically distant actors, contexts and institutional structures (Long, 2001). In Senegal, the main actors involved in policy and intervention processes are thus involved in coexisting arenas around flood management, for example, to access municipal flood response funding, to attract disaster risk management and climate adaptation resources to the country, to influence the direction of policy and to encourage popular support to political parties.

The existence of these diverse arenas suggests that interventions are instrumentalized by actors to serve diverse interests (such as strengthening professional positions and personal networks, satisfying donor country constituents, political power and private gain) through ongoing competition for different symbolic and material resources. Interventions are thereby shaped by a variety of actors who compete over the opportunities made available, where power is used and mobilized according to their various intentionalities (Gramming, 2002). They are all in possession of diverse mandates and resources and operate within distinct structural constraints, according to particular social logics, which together define their unequal positions of influence and thereby their room for manoeuvre within the arenas in which they operate. All arenas are highly inter-connected, these inter-connections being manifested differently, according to the situation in question. This conveys the need to consider the forms of interaction between the actors involved, their respective reasoning, their hidden agendas and the practical strategies adopted (Bierschenk and Olivier de Sardan, 1997). Since as objects of enquiry arenas have spatial, social and temporal dimensions, a key challenge is to trace where they are situated, who has access to them and how they occur. This perspective allows us to gain insight into the 'multiple realities' that influence the different interpretations of flood management interventions, where different meanings are attributed to interventions by diverse groups of actors. Consequently, the analytical concept of the arena is found to be particularly appropriate for the purposes of this paper because it marks the understanding of the flood management intervention processes followed in Senegal as political and social in nature, with actors using the opportunities created by interventions to serve their own interests and priorities. The approach followed in this paper considers mainly actor interests at the level of larger group logics (Long, 2001), rather than at the individual level. Ultimately, the analytical concept of the arena allows us to point towards some the underlying reasons for the disappointing achievements of flood management in Senegal.

\section{Methodology}

The primary data collection took place in Dakar, Senegal, in November 2012 and from January to April 2013. Qualitative explorative and semi-structured interviews (113) and informal conversations were conducted by Caroline Schaer, at the national, municipal and community levels 
in Dakar and in the two municipalities of Pikine/Dakar, Guinaw Rail Nord and Dalifort. Interviewees included representatives from ministries, national agencies and committees, semiprivate and private institutions, NGOs, experts international aid agencies, households, CBOs, municipal authorities, neighbourhood chiefs and religious leaders. Moreover, focus group discussions (7) with households and $\mathrm{CBO}$ members, supported by participatory diagramming methods, and attendance at public meetings also produced data. Interviews and focus group sessions were conducted with support from an interview guide, which was adapted to each category of respondent. These covered a wide range of issues, such as the views on the nature and effect of municipal, government and development actors' flood management approaches, flood impacts, governance configuration, trust, the history of activities, as well as the attitudes, perceptions and interactions among actors involved. At the municipal and community levels, most interviews were conducted in Wolof with a translator, while interviews at the national level were conducted in French. All interviews and focus group sessions were recorded and transcribed. The data was then coded (open and selective coding) and analysed with the aid of Nvivo software for qualitative analysis. The secondary data drawn on includes journal articles, grey literature (official reports and non-published reports gathered during interview sessions), an interpretative reading of the press, speeches and policy statements. Coding was also applied for secondary data analysis, where the data was coded with the help from the qualitative analysis software, according to i.e. concepts, approaches, theories and geographical contexts.

\section{Flood management interventions and policy in peri-urban Senegal}

Although sporadic government actions to assist flooded communities have been recorded as far back as 1962, when disaster victims from the village of Koungany received donations from former President Léopold Sédar Senghor (Dakar-Matin, 1962a; Dakar-Matin, 1962b), it was only under President Abdou Diouf (1980-2000) that floods became a recurring reality (in 1989 and between 1994 and 1999) in rural as well as urban areas in Senegal. This section provides a chronological narrative of the most important interventions and policies applied within the domain of urban flood management in Senegal since 2000, starting under the first government to take power after the democratic transition, that of the Senegalese Democratic Party (Party Démocratique Sénégalais $\left.\left(\operatorname{PDS}^{2}\right)\right)$.

\subsection{Interventions and post-disaster relief (2000-2005)}

The initial communication of the first Council of Ministers under the PDS regime (2000-2012), under President Abdoulaye Wade, emphasized the need to find a permanent solution to flooding in underserviced peri-urban areas (Sénégal, 2000). The PDS's stated commitment to addressing the problem of flooding gave hope to the populations affected (Thiam, 2013), who had thus far

\footnotetext{
${ }^{2}$ For the sake of clarity the French acronyms are maintained in the text. Organisations and programmes names in French and acronyms are listed in Annex 1.
} 
been left alone to deal with the challenges of living in underserviced flood-prone areas. The first manifestation of the government's commitment to address the problems encountered by residents in informal settlements was through the 'Restructuring and regularization of informal settlements policy (Politique de Restructuration et de Régularisation des quartiers spontanés (PRQS)). This policy was aimed at regularizing land tenure and restructuring infrastructure (electrification, roads, sanitation) in Pikine.

The main intervention, termed the 'Irregular Pikine South' (Pikine Irrégulier Sud (PIS)) project, was implemented by the semi-private organisation, 'Right to the city Foundation' (Fondation Droit à la Ville' (FDV)), and financed through a collaboration between the Government of Senegal, German cooperation bodies (GTZ and KFW) and the European Union. As a first step to regularizing peri-urban neighbourhoods, residents were offered a fifty-year right of occupation (droit de superficie) to replace the prevailing customary law (droit coutumier) under which they had acquired their property. However, as they had to pay for the plot, many residents did not see the benefit of regularising their ownership arrangements, and the illegal occupation (occupation irrégulière) of the land continued. The focus on restructuring was straightforward at the time, as the need for urban restructuration programmes (programmes de restructuration) to develop periurban areas with irregular settlements, thus solving the recurring flooding problems, has pervaded the discourses of the government and donors in respect of solutions to flooding in the country for years. restructuring programmes were perceived as a panacea for all difficulties facing flood-threatened areas by both the general population and public authorities alike. According to interviewees from the municipal development agency (ADM), who is the lead institution in charge of developing a master plan for storm-water management in flood prone zones, there were disparate understandings of what 'restructuring' entails, programmes often equated new roads with the rehousing of residents, while underlying issues such as sanitation and rainwater drainage were mainly approached on a small scale and in an ad-hoc manner.

Another main intervention for flood disasters was initiated at the time, the 'National Relief Coordination Plan' (Plan National d'Organisation des Secours (Plan ORSEC)), which was directly the responsibility of the government. The ORSEC plan was (and still is) implemented by the Directorate of Civil Protection (Direction de la protection civile (DPC)), the formal national risk prevention and disaster management mechanism under the Ministry of Interior. The 'High Commission for Civil Protection' (Commission Supérieure de la Protection Civile (CSPC)), created in 1999, served as the advisory body for the Minister of Interior on civil protection issues and for the coordination of sectoral activities in disaster prevention and relief. The ORSEC plan has been initiated repeatedly since then as a contingency plan aimed at minimizing disaster risks, as well as organizing and coordinating the national disaster response. However, in practice initiatives implemented under the plan are to this day still mainly restricted to limited acute relief, such as water-pumping and channel-digging by the fire brigade and the temporary evacuation of affected 
households to schools and/or military camps. The ORSEC plan is still under-resourced, and the means provided to fight flooding are considered derisory compared to the actual and acute needs of the population. In addition, several coordinating bodies for flood response were created, including the 'National Commission for the Management and Planning of Flooding' (Commission Nationale de Gestion Prévisionelle des Inondations (CONAGPI)) in 2001 and the 'National Unit for the Prevention and Fight against Flooding (CNPLI) in 2003, among others (see Table 1).

The 'National Office for Sanitation' (Office National de l'Assainissement du Sénégal (ONAS))was created in 2003 upon the formation of the Ministry of Environment and Sanitation for the execution of tasks related to sanitation. These tasks were divided between ONAS and the Sanitation Directorate, which are to this day organized in the same manner. The Directorate is responsible for the formulation of policy, programmes and projects nationally, while ONAS's main responsibility is the disposal of wastewater in the regulated areas of Dakar. To a large extent this excludes peri-urban areas and rainwater evacuation. ONAS is responsible for closed channels, while open channels are the responsibility of local municipalities, in spite of the limited resources they have to ensure maintenance and cleaning (ADEPT, 2010).

As urban flooding gradually worsened between 2000 and 2005, isolated government programmes and projects were formulated with support from international and bilateral organizations, such as the 'Sanitation Programme for Peri-urban Areas' (Programme d'Assainissement des Quartiers Péri Urbains de Dakar (PAQPUD)), the 'Long-term Water programme' (Programme Eau à Long Terme (PELT) and the 'Millennium Sanitation and Drinking Water Programme' (Programme d'Eau Potable et d'Assainissement du Millénaire (PEPAM). In addition, numerous NGOs and international organizations have emerged in flooded municipalities over the years (see Table 3 in Annex) to provide affected populations with relief assistance and other support, many only to disappear again. Interventions were in general mainly restricted to rudimentary relief and smallscale initiatives such as the provision of motor pumps, the creation of water retention basins (often of insufficient capacity and posing safety risks in their own right) to capture the surplus of water, the construction of open channels for water evacuation, the provision of simple pipe systems and channels, and the distribution of food and non-food items. Some victims received monetary compensation for their resettlement.

The general absence of programmes to promote a basic infrastructure adequate for flood management such as rainwater drainage and sanitation was, according to national experts, characteristic of a government approach whereby a request for international aid and limited immediate relief once the floods had become a reality was the preferred strategy. While government policy and donor interventions between 2000 and 2005 may be summarized as consisting of expensive and unsustainable seasonal and relief support and minor infrastructural improvements to flooded areas, from 2005 their emphasis was on the policy of social housing. 


\subsection{Housing construction policy (2005-2008)}

Disastrous floods changed the electoral calendar in 2005 when President Wade postponed parliamentary elections allegedly to save the 52 billion Francs Communauté Financière Africaine (FCFA) allocated to the elections and divert them to help flood-affected victims through a new policy of social housing construction ${ }^{3}$. Parliamentary elections were then planned to be coupled with the presidential elections of 2007, though ultimately they were not. Quite the opposite, the costs of the postponed elections increased substantially, and the government was accused of having taken them from the funds that had been collected and earmarked for the new policy of social housing construction (Thiam, 2013). The policy entailed the permanent relocation of households living in some of Pikine's high-risk areas. It was implemented under the 'Jaxaay Plan' (Plan Jaxaay) and the 'One Family, One House' programme, initially under the National Agency against Floods and Slums (ANLIB), which had been taken over by the Ministry of Architectural Heritage, Housing and Construction. The objective of these interventions was to compensate the worst affected households for the loss of their houses by constructing 4000 new houses in a new location (the 'Cité Jaxaay'), as well as building retention ponds and gravity-based drainage systems.

These interventions came under heavy criticism from many camps. First, they were alleged to have been poorly conceived technically. Being a prototype of responses to irregular settlements and flooding, ironically the 'Cité Jaxaay' did not benefit from a proper sanitation system and adequate rainwater evacuation drainage, and experienced flooding itself in 2010, 2011 and 2012. Secondly, the programme was subject to accusations of fraud, and civil-society critics and current government representatives both saw it as a pretext for the former government to postpone elections and to collect significant funding, while relocating only a negligible number of affected households (Senegal Post, 2014). Unsurprisingly, some members of the PDS, now in opposition, see these criticisms as a political move by the present president, Macky Sall, to harm them (Le Soleil, 2013). In addition, the resettlement strategy turned out to be too expensive at the time of realization, as well as inadequate in view of the extent of the damage sustained and the number of victims, according to national experts in the field.

\subsection{Decentralisation and the first post-disaster needs assessment (2008-2012)}

From 2008 to 2012, policies, plans and interventions to address urban flooding were repeatedly formulated, many of them to be abandoned soon afterwards, such as the 'National Contingency Plan', which was validated in 2008, but has never been implemented. s. By the same token, some of the projects formulated before this period have never been carried out. For example, the 'One Family, One House' programme was initiated in 2006 but never materialized; the project in support of the 'National Disaster Prevention, Reduction and Management Programme' was formulated in

\footnotetext{
${ }^{3}$ The new policy consists of resettling people displaced from flood zones into houses which are constructed and subsidized by the state. Beneficiaries pay $15 \%$ of the value of the house over a period of fifteen years.
} 
2011, but nobody has heard anything about it since then. Similarly, platforms and committees established to address urban flooding have proved to have a short life-span. For example, the 'National Platform for the Reduction of Major Disaster Risks' (Plateforme Nationale pour la Réduction des Risques Majeurs de Catastrophe (PNRRMC)), which shares the same role as the CSPC and was established in 2008, in line with HFA recommendations, was no longer operational in 2012.

According to interviewees from flood prone areas, experts and government officials, this period is characterized by the strong unpopularity of the regime in power, partly due to their poor management of floods, the misuse of the funds allocated to the 'Plan Jaxaay' being a key issue of popular discontent. The unpopularity of the government culminated in violent demonstrations in peri-urban municipalities where floods had been recorded and a reversal for the political majority by the opposing coalition, 'Benno Siggil Senegaal' (BSS) (united to rebuild Senegal), who won the municipal elections in March 2009. The voting percentage in Pikine was at its lowest (15\%) for these elections, which is by experts (Thiam, 2013) and residents of Pikine mainly attributed to the government's poor management of floods.

In spite of the derisory human and financial resources available to municipalities in order to tackle floods this task was decentralized by Wade's government after the BSS opposition coalition came to office in the major urban agglomerations of the country. The BSS coalition's attempts to live up to the promises it had made during municipal elections turned out to be just as short-term and fragmented as the approach followed by the former power-holders, consisting mainly of water pumps, sewage pumping, and temporary channel digging.

Following the 2009 floods, the 'Post-Disaster Needs Assessment' (PDNA), funded through the Global Facility for Disaster Reduction and Recovery (GFDRR) by the World Bank and the Government of Senegal, estimated the rehabilitation and reconstruction needs and costs in Dakar at more than 204.5 million USD. ${ }^{4}$ The report identified a number of priority measures, which included (1) preparing a master plan for storm-water management, (2) establishing a system for storm-water drainage in priority areas in Pikine and (3) preventing and mitigating disasters by developing an urban development plan (GFDRR et al., 2014). In order to implement these priority measures, a 'Rainwater Management and Climate Change Adaptation Programme' (Projet de Gestion des Eaux Pluviales et d'Adaptation au Changement Climatique (PROGEP)) was initiated by the government's 'Municipal Development Agency (Agence de Développement Municipal $(\mathrm{ADM}))^{5}$ with support from the World Bank, the Nordic Development Fund and the African

\footnotetext{
440.7 million USD for rehabilitation and 163.8 million USD for reconstruction and disaster risk reduction. ${ }^{5}$ The ADM was created in 2009 by the Government of Senegal in collaboration with donors in order to support decentralisation processes.
} 
Development Bank (AfDB) (République du Sénégal 2011), in peri-urban areas of Dakar. The aim of the programme is to integrate flood risks in urban planning, improve urban planning conditions and construct an extensive drainage system, based on the master plan for rainwater drainage (Plan Directeur de Drainage des Eaux Pluviales (PDDEP-2011), in collaboration with the 'National Agency for Investment Promotion of Large Scale Construction' (Agence des Grands Travaux (APIX)), while reinforcing the institutional capacity of the actors operating in this area.

\subsection{A new regime and a ten-year flood management programme (2012)}

In 2012 exceptionally high rainfall was seen across West Africa, which resulted in deadly floods in the capital of Senegal, where 26 people lost their lives. Residents took to the streets of the capital to denounce the government for failing to act on the floods. In response, the newly appointed President Macky Sall (from the Alliance Pour la République (APR) party) promised that the money reserved for the Senate would instead be allocated to a new Ten Year 'Flood Management Programme' (Plan Décennal de Gestion des Inondations (PDGI) 2012-2022), in order to support flood victims. Members of Parliament voted to abolish the Senate, and the post of vice-president was eliminated by Congress, although no one had held the position since it had been created in 2009 by former President Abdoulaye Wade. It is unclear how much of the money set aside for the Senate was actually diverted to the implementation of the PDGI. The PDGI consists of an emergency phase and a ten-year programme to develop infrastructure for the evacuation of rainwater through an unprecedented drainage system; it is being implemented by the ADM in collaboration with the ONAS, with support from the World Bank. Implementation of the PDGI has been planned in detail, with costs totalling 720 billion FCFA in 2022, and it is currently being implemented. There is still a lack of clarity over the distribution of roles for implementing the diverse components of the PDGI and some insecurity as to future funding, which is mobilized annually. Moreover, the focus is mainly on rainwater evacuation, the provision of comprehensive sanitation not being included. Allocations for the 2012 floods amounted officially to 66 billion FCFA, while the total costs of the PDGI amounts to 720 billion FCFA. Allocations for flood management thus went from 2 to 66 billion FCFA between 2000 and 2012. During the 2012 floods, in addition to new external aid (from France, Union Economique et Monétaire Ouest Africaine (UEMOA), Economic Community Of West African States (ECOWAS) and World Bank among others), the largest amount of televised fundraising and largest private donations to date were registered, but unfortunately the allocation of the funds collected created controversy, as they were first earmarked for the Ministry of Interior in charge of the DPC, which is responsible for the implementation of the ORSEC Plan, and were later allocated to the Ministry of Finance. Whether the funds have been used for the planned purposes is still an issue of public dispute (Fall and Diedhiou, 2013). As is the case for most disbursements and the spending of public emergency funds, procedures are complex and lengthy and lack transparency (GFDRR et al., 2014). 
The new regime of President Macky Sall created a ministry exclusively for the management of flood zones, the 'Ministry of the Restructuring and Development of Flood Zones'5 (Ministère de la Restructuration et de l'Aménagement des Zones d'Inondation (MRAZI)), which was supposed to consolidate the national response to floods. With the stated objective being to promote sustainable flood management through effective prevention, the development of sustainable solutions and the resettlement of flood victims, the creation of the new Ministry was presented as an expression of the government's commitment to reorganizing the failed flood response and to assign floods to a specific government organ. However, the reality turned out to be disappointing. The MRAZI did not manage to define its role clearly before it was replaced in July 2014 by the Ministry of Restructuring and Reclassification of Suburbs ${ }^{6}$ under the authority of the Ministry of Urban Renewal, Housing and Living Environment. The new Ministry's stated attempt at achieving synergy between stakeholders scattered throughout the complex field of flood management focuses mainly on the reorganization of municipalities that are prone to flooding by means of social housing construction programmes. During the 2013 floods the President revealed a new public housing construction program ('Yakaar City'), a prolongation of the failed Plan Jaxaay. The Yakaar City programme was partly delivered during the 2014 rainy season, disregarding residents from previously flooded sites in Guédiawaye, Médina Gounass and Djeddah-Thiaroye-Kao, where flood victims have been waiting to be resettled since 2005 (under Plan Jaxaay). The role played by the Fondation Servir le Sénégal (a foundation lead by Marième Faye Sall, the wife of President Macky Sall) in the relocation of residents and the ORSEC plan has become the subject of extensive criticism and debate in the press, because of the lack of transparent funding allocations and the alleged influence of party politics in its activities.

\section{Discussion}

The analysis of the configuration of flood management policies and programmes in urban Senegal depicted above points to three key intertwined issues, which have influenced the limited achievements within the domain of flood management in urban areas. These include, but are not restricted to, the political and personal appropriation of flood management-related processes, the reinforcement of the dichotomy between central government and municipalities, and a fragmented institutional framework, with overlapping and competing institutions.

\subsection{Political and personal appropriation of flood management processes}

The account of flood management interventions in Senegal illustrates the significance of the political appropriation of the flooding issue. This appropriation is visible through a number of momentary periods of symbolic activity in the arena of national politics. One example was the

\footnotetext{
${ }^{5}$ Décret n 2013-163 du 25 janvier 2013.

${ }^{6}$ Décret n²014-899 du 22 juillet 2014.
} 
postponing of parliamentary elections and the abolition of the Senate. These symbolic acts were linked to major flood events and were claimed to be in support of the disaster-stricken population. However, rather than such acts of support, they could be seen as ways of holding on to political power in a difficult political situation and of weakening the opposition, which had a

majority in the Senate. The Plan Jaxaay, which was only partly financed by the savings made from postponing the parliamentary elections, was promoted in the media not only as a technical and sustainable solution to the issue of flooding, but almost as a personal gift from the President to the ruling party. The likely substantial misuse of funds and the fact that in reality they only reached a very limited percentage of those who were in need, indicate that the main purpose of the Plan Jaxaay was to make the government's commitment concretely visible prior to the elections and thereby increase its popularity. In other words, politicians were not only seeking for the most appropriate solutions to address the flooding issue, they were mainly using a symbolic disaster response in order to influence their prospects of re-election.

Another example of symbolic activity in the arena of national politics was the creation of the Ministry for Floods (as MRAZI was baptized in everyday language) by the new regime in power under President Macky Sall. Although presented as an expression of the government's dedication to solving the recurrent flood issue, the creation of the new ministry was more symbolic than followed by tangible actions. The Ministry's assignment decree was limited in scope and included mainly the Social Housing Construction Programme to Prevent Slums (PCLSLB), previously under the responsibility of the Ministry of Water. MRAZI did not manage to define its role clearly or set an agenda within the field of flood management before it was closed. With its limited mandate and lack of achievements, MRAZI thus proved to be a short-lived political response to a structural and institutional problem, which nonetheless allowed the government to demonstrate a strong national commitment to resolving the floods issue, without dedicating sufficient resources to tackling the core of the problem.

The examples above were related to the arena of national politics, but as we shall see below, access to international donor funding constitutes an important arena for the exclusion of political rivals at various political levels. The positioning and negotiations in the arena of donor funding are complex due to poorly formalized and mainly ad hoc flood management mechanisms and coordination processes. As a result, actors from opposition parties risk being excluded from access to and control over external funds. One example of political exclusion concerns the World Bankfinanced PROGEP programme, which was started prior to the presidential elections in 2012. In the PROGEP programme observers considered the Regional Development Agency (Agence Régionale de Développement (ARD)) and the Regional Council of Dakar (CRD) to be important and relevant stakeholders in the process, but nevertheless they were finally excluded from the negotiating table and piloting committee (Mane, 2011). While there might be several reasons for 
this, most observers see this as a matter of politics because the two excluded institutions were headed by the opposing coalition (Alliance pour les Forces du Progrès). Other examples of such party-political exclusions are found across all levels of governance (see section 5.2).

As a result of the political and personal appropriation of flood management resources and processes and the lack of achievements within the domain of flood management, a certain fatigue and lack of concern in this area are widespread among the actors involved, as well as widespread suspicion and accusations, as articulated by an expert who has been involved in the design and implementation of several government-led flood management initiatives: 'In fact there are people from the government and others, who do not want this matter (flooding) to end, they don't want lasting solutions. It's like in war, if the war ends, I don't' sell my arms anymore, I lose my job, I have no work, I'm not paid, I don't manage anything, I don't have my billions anymore'. The populations affected by floods and the many actors involved in flood responses at the national and municipal levels suspect that flood management interventions are being diverted from their original purpose of supporting victims in order to fulfil diverse political and personal interests. This fosters considerable rumours about the practises attached to interventions at multiple levels and interventions are thus in deficit of legitimacy from the very outset. In addition to the poor results of flood management, suspicions regarding the political and personal appropriation of funds are fuelled by the inoperative and non-formalised coordination mechanisms, the limited documentation of fund disbursements and use, and the opacity surrounding the roles of some of the actors involved, according to actors involved in the implementation of national flood risk mitigation interventions and experts. The relatively short time span of many project and programmes and the insecure mobilization of annual funds for longer term programmes such as the PDGI points in the same direction. The prevalence of accusations and suspicions undermines the creation of minimal relations of confidence and trust, which are central to the satisfactory delivery of floodrelated interventions and services. According to Olivier de Sardan (2009), this is a general phenomenon one can observe with respect to the delivery of public and collective services in francophone West Africa.

Consistent with the actor-oriented perspective applied here (Olivier de Sardan, 2005), the example from the national arena of politics, illustrate that flood management interventions and processes followed in Senegal are political and social in nature, with actors using the opportunities created by interventions to serve their own interests and priorities. Interventions as socially constructed and negotiated processes (Long and Ploeg, 1989), which is found to be key to understanding the limited accomplishments within the domain, is not captured in the conventional linear thinking behind ideal-type donor intervention, where problems may be identified and followed by suitable actions, which together result in foreseeable outcomes (Mosse, 2004). These findings support those of Bang (2014) and Thiam (2013), who reveal how government administrations in West Africa use disaster management interventions as symbolic actions to promote their positions during election campaigns. 


\subsection{Reinforcement of the dichotomy between central government and municipalities}

According to expert interviews, conflicts over the attribution of responsibility for flooding, for addressing impacts and for channelling support have long prevailed between national government and decentralised municipalities. This conflict was exacerbated in 2009, when the Benno Siggil Senegal (BSS) opposition coalition was elected to govern the major cities of the country over former President Abdoulaye Wade's party. This had an impact on flood management because these cities had experienced recurrent flooding and because municipalities run by the opposition party were penalized by being allocated derisory financial, physical and human resources to fight floods. In a number of cases, the most serious aspect was the decision to devolve responsibility for flood management from national government to local municipalities, without the allocation of new general funding. The governmental resources earmarked for municipalities through the Fonds d'équipement des collectivités locales and the Fonds de dotation de la decentralisation was already minimal and inadequate for most municipalities, and not sufficient for the new flood management obligations. Observers therefore saw this measure of decentralization as a general penalty imposed on the major cities run by the opposition.

In addition to the general penalization of opposition-run municipalities described above, the post2009 period also provide examples of how specific municipalities were favoured according to their political affiliations. For example, according to expert interviews, the mayor of the municipality of Thiaroye sur Mer, who was affiliated to the Senegalese Democratic Party in power, received substantial support from the central government, while the mayor of Dalifort, who was from the opposition socialist party, was completely neglected. The party-political interference from central government in the management of municipal affairs is nothing new and has been practised by various governments. It began during the socialist era under President Senghor (1960-1980), where public drinking fountains were installed according to the political affiliations of the neighbourhood delegates ('délégués/chefs de quartier') to whom they were awarded (Salem, 1992). The same methods were observed by the former Prime Minister, Souleymane Ndiaye Ndéné, who in 2009 visited flooded areas and allocated the sum of FCFA 10,000,000 to municipal officials from the PDS party while neglecting officials from the opposition.

As a result of the exclusion of the political opposition described above, municipal-level actors struggle to define and defend their own positions through individualized transformations of processes and personalized strategies. This was the case for a Pikine mayor, who revealed his special advantage in using his personal networks in the DRR coordinating framework, to tap into municipal flood response support and access support from the ORSEC plan for his municipality: 'I hear other mayors complaining about their needs, but in my case my needs are taken care of by the Orsec program. I have special relations with the leaders of the (ORSEC) plan, I know whom to go to if I need something, I have 
networks everywhere'. Or when the president of the coordination agency for community-based work in the Pikine municipality of Guinaw Rail Nord explained that he had to use informal channels to access information from which he was excluded regarding the flood management plans for his area. These alternative appropriations of flood management processes co-exist with the formal procedures, mandates and plans laid out for flood management at multiple levels, in, for example, the High Commission for Civil Protection (CSPC) and coordinating bodies such as the National Platform for the Reduction of Disaster Risk (PNRRMC).

As described above, the negotiation of both inclusion in and exclusion from flood management processes and arenas takes place across distinct levels of governance and is fuelled by the significant aid provided to the national level, which rarely trickles down to the municipal level. These processes are part of a more general phenomenon described by Reisnick (2014) in which vertically divided authority, i.e. opposition parties entering office at the municipal level, are perceived as a threat to service delivery at the municipal level. As has been shown, the struggle for resources and influence between the state centre and peripheral municipalities over flood interventions is found to reinforce existing dichotomies between state and municipality, interventions being used as vehicles for political projects, as described also by Lund (2007) in different contexts. It is thus not always the most appropriate or competent actors who are involved in interventions, but those who have most influence over the processes in their respective arenas.

The example from flood management in Senegal shows that the relationship between national government and decentralised municipalities is key to understanding the configuration of flood risk management in Senegal. Consistent with the actor-oriented perspective applied here (Long and Ploeg, 1989; Bierschenk, 1988; Bierschenk and Olivier de Sardan (1997)), the unequal positions of influence of state actors at the different levels of governance and the resulting diverging interests and conflicting motives they hold, is found to have direct implications for how flood management interventions have been approached in the country, where the prospects for municipalities to play an actual role in addressing floods are marginal.

\subsection{Institutional fragmentation and overlaps}

The narrative in section 4 shows that numerous coordinating mechanisms, institutions and ministries have been created and restructured, seemingly without a concerted government vision, and often to comply with international policy frameworks (such as the HFA) or at the request of international development partners. Policies and plans have often been formulated in isolation from one another, with little horizontal integration. Accordingly, the coordination of flood management takes place separately within the respective sectors, by new institutions put in place without dissolving the old ones, and often with short lifetimes. 
The shifting and unsuccessful designations of a coordinating body for flood response management listed in Table 1 demonstrates this process of putting new institutions in place without disbanding old ones. In 2001, the National Commission for the Management and Planning of Flooding (CONAGPI) was established. In 2003, the similar National Unit for the Prevention and Fight against Flooding (CNPLI) was instituted. In 2004, a National Unit for Flood response is created, followed by the establishment of the National Committee on Flood Prevention, Supervision and Monitoring (CNPSSLI) in 2007. In 2008 the National Platform for the Reduction of Disaster Risk (PNRRMC) was set up at the request of development agencies to be coordinated by the Prime Minister's office. It is supposed to be an advisory and consultative body for all stakeholders involved in disaster risk management, including flood management policies and programmes, but has hardly been operational since its creation.

\begin{tabular}{|l|l|l|}
\hline Coordination Mechanism Designation & Role & Year \\
\hline Directorate of Civil Protection (DPC) & $\begin{array}{l}\text { Coordination of national flood } \\
\text { response and national relief } \\
\text { organisation Plan (Plan } \\
\text { ORSEC) }\end{array}$ & 1999 \\
\hline $\begin{array}{l}\text { National Commission for the Management and } \\
\text { Planning of Flooding (CONAGPI) }\end{array}$ & Implemented but not operational & 2001 \\
\hline $\begin{array}{l}\text { National Unit for the Prevention and Fight against } \\
\text { Flooding (CNPLI) under the Ministry of Interior }\end{array}$ & Implemented but not operational & 2003 \\
\hline National Unit for Flood Response & $\begin{array}{l}\text { National response and coordination; } \\
\text { food aid and hygiene kits }\end{array}$ & 2004 \\
\hline $\begin{array}{l}\text { National Committee on Flood Prevention, } \\
\text { Supervision and Monitoring (CNPSSLI) }\end{array}$ & Flood prevention and preparedness & 2007 \\
\hline $\begin{array}{l}\text { National Platform for the Reduction of Disaster Risk } \\
\text { (PNRRMC) }\end{array}$ & $\begin{array}{l}\text { Coordination of disaster risk reduction } \\
\text { activities; follows Hyogo Framework of } \\
\text { Action (HFA) recommendations }\end{array}$ & 2008 \\
\hline National Flood Prevention Office (ONPI) & $\begin{array}{l}\text { Coordination of storm water drainage } \\
\text { management }\end{array}$ & 2012 \\
\hline National Flood Committee (NILC) & $\begin{array}{l}\text { Coordination of the implementation of } \\
\text { action plans resulting from the national } \\
\text { strategy }\end{array}$ & 2009 \\
\hline
\end{tabular}

Table 1. National flood management coordination mechanisms in Senegal.

Another example of institutional overlap is the establishment of MRAZI as described in section 4. In this case an overlap between MRAZI's mandate and other ministries already involved in flood management (see Table 2 in Annex 2) merely augmented the disorder and competition among government actors.

On the other hand this situation, where institutions with different purposes intersect and even change into one another, creates different layers of influence and legitimacy, which co-exist in the same socio-political space. According to representatives from development agencies, NGOs, semi- 
private agencies and state institutions, this generates confusion as to their roles and responsibilities, since their reciprocal interrelations and fields of competence are inadequately defined and poorly formalized, This is observable, for example, in the case of the DPC, which, in spite of its formal role, never managed to play a leadership or coordinating role with respect to flood response in Senegal. To this day the general coordination of policies, programmes and projects related to flood management has not been attributed to the DPC, or any of the other coordination mechanisms, but has been dispersed among several ministries (such as the Ministry of Interior, Ministry of Family and Solidarity, Ministry of Habitat, Water), agencies (i.e. ADM), decentralised actors (local municipalities), and private and semi-private companies (i.e. FDV, the Sanitation Office of Senegal (ONAS)), with very limited coordination among them and scattered mandates and prerogatives. The ambiguity entailed by these practises has led to competition between disaster responses, duplicate mechanisms and the ongoing 'negotiation' over competencies and interpretations of mandates in the domain of flood management in Senegal. In the absence of clear mandates and binding documents in the domain, this also creates inertia at the highest political level, according to government agents and expert.

The practice of confusing mandates and piling up institutions can be seen partly as the result of the political and personal appropriation of the flood management processes described in section 5.1, and partly as the result of numerous fragmented donor interventions. As we have seen in this case, and as has been illustrated by the seminal work of James Ferguson (Ferguson, 1994), donor interventions tend to create new structures and institutions so that they can keep control over their own resources, but also because donor interventions have the resources to create new institutions, while on the other hand alone being in a position to recommend abandoning old ones. Leading to the same result, individual and institutional actors will try to position themselves in new arenas and propose new organisational structures in their struggle for material and symbolic resources.

The piling up of institutions described here, which is found at the national level in Senegal, has also been established for flood management processes at the local level in peri-urban Senegal, where the local state is found to be negotiated and translated differently through a number of diverse formal and informal actors (Schaer and Hahonou, forthcoming). The findings presented here also resonate with a wider body of literature concerning West Africa documenting how institutions, mainly at the local level, pile up, overlap and intersect in contexts which enjoy a high level of donor support (Bierschenk et al. 2000; Nygaard, 2008).

\section{Conclusion}

This article has investigated how floods have been managed in urban Senegal during the last fifteen years and asked why it has not led to the results expected by the population, state institutions and the donor community. The paper has provided a narrative of the most important interventions 
and policies applied within the domain of urban flood management in Senegal since 2000, starting under the first regime in power after the democratic transition, that of the Parti Démocratique Sénégalais (PDS).

This was followed by an analysis of the configuration of flood management policies and programmes, which points towards three interconnected issues that have influenced the limited achievements within the domain of flood management in urban areas. First, the political and personal appropriation of flood management processes is found to be a practice creating a culture of rumours, distrust and apathy among the actors involved in flood management. Secondly, the reinforcement of the existing dichotomy between central government and decentralised municipalities, where party politics is used strategically to marginalize peripheral actors from the opposition, has reduced the resources applied to flood management. Lastly, a

fragmented institutional framework with overlapping institutions, duplicate mechanisms and an ongoing 'negotiation' of competencies and interpretation of mandates has limited the impact of flood management in Senegal.

While the explanatory structural and historical factors for scarcities in service provision in urban and peri-urban centres (Gandy 2006; Nunan and Satterthwaite 2001; Resnick 2014b; Resnick 2014a.) and the disaster risk reduction measures that have been adopted in the region (Diagne and Ndiaye 2009; Gaye and Diallo 1997; Diagne 2007) have been the object of analysis, limited research has examined the governance mechanisms, institutions and actors involved in urban DRR and CCA in the region (see Bang 2014; Thiam 2013). By applying an actor-oriented perspective, the article goes a step further by showing that actors involved in policy and flood intervention processes are competing in coexisting arenas around flood management, to access municipal flood response funding, to attract disaster risk management and climate adaptation resources to the country, to influence the direction of policy and to encourage popular support to political parties. Consequently, because of the limited resources available for governments such as the Senegalese, development funding for disaster risk management and climate adaptation in the domain of urban flooding is found to be an important part of the solution to dealing with repeated flooding. Paradoxically, as exposed in this paper, it is also a part of the problem. The 'commodity' approach to flood management engendered by substantial development funding produces and legitimises certain practises and interests, which may work against the very objectives of flood management interventions. While this has been described by several authors locally (Lewis and Mosse, 2006; Smith, 2006; Bierschenk et al., 2000; Bierschenk, 1988), relatively little work has exposed this issue nationally, a theme to which this article forms a contribution. The findings presented here convey the need for a more profound understanding of the contextual processes, interests and mechanisms behind disaster risk management and climate change interventions in general and flood management in particular, so that interventions can meet both the current and future challenges of a changing climate. 


\section{References}

Adger, W. N. (2000). Institutional adaptation to environmental risk under the transition in Vietnam. Annals of the Association of American Geographers, 90(4), 738-758.

Agrawal, A., McSweeney, C., \& Perrin, N. (2008). Local insti-tutions and climate change adaptation. Washington, DC: World Bank.

Amicale des Diplômés de l'Ecole Polytechnique de Thiès (ADEPT). (2010). Les inondations à Dakar et banlieue: Mieux comprendre les causes pour des solutions durables (Thiès). Colloque scientifique.

Bang, H. N. (2014). General overview of the disaster management framework in Cameroon. Disasters, 38(3), 562-586.

Bhavnani, R., Vordzorgbe, S., Oswor, M., \& Bousquet, F. (2008). Report on the status of disaster risk reduction in the Sub-Saharan Africa region. Washington, DC: Commission of the African Union, UNISDR, World Bank.

Bierschenk, T. (1988). Development projects as arenas of nego- tiation for strategic groups: A case study from Bénin. Sociologia Ruralis, 28, 146-160.

Bierschenk, T., Chauveau, J.-P., \& Olivier de Sardan, J.-P. (2000). Courtiers en développement: les villages africains en quête de projets. Paris: APAD, Karthala.

Bierschenk, T., \& Olivier de Sardan, J.-P. (2014). Ethnographies of public services in Africa: An emerging research paradigm. In T. Bierschenk \& J.-P. O. de Sardan (Eds.), States at work - dynamics of African Bureaucracies (1st ed., Part one, pp. 35- 65). Leiden: Koninkijke Brill.

Bierschenk, T., \& Olivier de Sardan, J.-P. (1997). ECRIS: Rapid collective inquiry for the identification of conflicts and stra- tegic groups. Human Organization, 56(2), 238-244.

Dakar-Matin. (1962a). Le Sénégal au secours des sinistrés de Koungany. Dakar-Matin, (5.7), p. 6. Dakar.

Dakar-Matin. (1962b). 1048344 F pour les sinistrés de Kounghany. Dakar-Matin, (25.9), p. 3. Dakar.

Diagne, K. (2007). Governance and natural disasters: Addressing flooding in Saint Louis, Senegal. Environment and Urbanization, 19(2), 552-562.

Diagne, K., \& Ndiaye, A. (2009). History, governance and the millenium development goals: Flood risk reduction in Saint- Louis, Senegal. In M. Pelling \& B. Wisner (Eds.), Disaster risk reduction - cases from urban Africa (pp. 147-166). London: Earthscan.

Diouf Babacar, P. (2009). L'ingénierie economique et sociale dans les projets de lutte contre l'habitat insalubre à Dakar, Pikine et Guédiawaye (Sénégal). In J. Le Tellier \& A. Iraki (Eds.), Habitat Social au Maghreb et au Sénégal - gouvernance urbaine et participation en question (p. 225). Paris: L'Harmattan.

Fall, H., \& Diedhiou, A. (2013). La bombe dans les eaux Sall du Macky. L'Observateur N. 2921. Dakar.

Fall Salam, A., Guèye, C., \& Tall Mansour, S. (2005). Changements climatiques, mutations urbaines et stratégies. In A. Fall Salam \& C. Guèye (Eds.), Urbain-Rural: Phybrida- tion en marche (p. 191). Dakar: enda tiers-monde.

Fatti, C., \& Patel, Z. (2013). Perceptions and responses to urban flood risk: Implications for climate governance in the South. Applied Geography, 36, 13-22.

Ferguson, J. (1994). The anti-politics machine: "development", depoliticization, and bureaucratic power in Lesotho. Minneapolis: University of Minnesota Press.

Gandy, M. (2006). Planning, anti-planning and the infrastructure crisis facing metropolitan lagos. Urban Studies, 43(371), 371-396.

Gaye, M., \& Diallo, F. (1997). Community participation in the management of the urban environment in Rufisque (Senegal). Environment and Urbanization, 9(1), 9-30. 
Global Facility for Disaster Reduction and Recovery (GFDRR), UNDP, EU \& Government of Senegal. (2014). Senegal: Urban floods - recovery and reconstruction since 2009. Dakar: Author.

Government of Senegal \& World Bank. (2013). Economic and spatial study of the vulnerability and adaptation to climate change of coastal areas in Senegal: Synthesis report. Dakar: Author.

Government of Senegal, World Bank, UNDP \& EU. (2010). Assessment report on post-disaster needs, urban floods in Dakar 2009. Dakar: Author.

Gramming, T. (2002). Technical knowledge and development observing aid projects and process. London: Routledge.

Kern, K., \& Alber, G. (2009). Governing Climate Change in Cities: Modes of Urban Climate Governance in Multi-level Systems. Competitive Cities and Climate Change. OECD Conference Proceedings, Milan 171-196.

Le Meur, Y. P., \& Blundo, G. (2009). The governance of daily life in Africa: Ethnographic explorations of public and collective services. Boston, MA: Brill, Hotei Publishing.

Le Soleil. (2013). Affaire du plan J AXAAY, Oumar Sarr: " Le Premier ministre Macky Sall avait approuvé la plupart des marchés". Le Soleil. 12.7. Dakar.

Lewis, D., \& Mosse, D. (2006). Development brokers and translators. The ethnography of aid and agencies. Bloomfield, CT: Kumarian.

Lindell, I. (2008). The multiple sites of urban governance: Insights from an African City. Urban Studies, 45(9), 1879-1901.

Long, N. (2001). Development sociology - actor perspectives.

New York, NY: Routledge.

Long, N., \& Ploeg, J. D. Van Der. (1989). Demythologizing planned intervention: An actor perspective. Sociologia Ruralis, 29, 226-249.

Lund, C. (2006a). Twilight institutions: An introduction.

Development and Change, 37(4), 673-684.

Lund, C. (2006b). Twilight institutions: Public authority and local politics in Africa. Development and Change, 37(4), 685-705.

Maguire, B., \& Hagan, P. (2007). Disasters and communities: Understanding social resilience. Australian Journal of Emergency Management, 22(16), 16-20.

Mane, L. (2011). 35 milliards de la banque mondiale opposent Wade et Gakou. Actualité. Dakar.

Mbow, C., Diop, A., Diaw, A. T., \& Niang, C. I. (2008). Urban sprawl development and flooding at Yeumbeul suburb (Dakar-Senegal). African Journal of Environmental Science and Technology, 2(4), 75-88.

Migdal, J. S. (2001). State in society: Studying how states and societies transform and constitute one another. Cambridge: Cambridge University Press.

Migdal, J. S., \& Schlichte, K. (2005). Rethinking the state. In K. Schlichte (Ed.), The dynamics of states. The formation and crises of state domination (pp. 1-40). Aldershot: Ashgate.

Mosse, D. (2004). Is good policy unimplementable? Reflections on the ethnography of aid policy and practice. Development and Change, 35(4), 639-671.

Nunan, F., \& Satterthwaite, D. (2001). The influence of govern- ance on the provision of urban environmental infrastructure and services for low-income groups. International Planning Studies, 6(4), 409-426.

Nygaard, I. (2008). External support to local institutions: Providing political leverage to weaker groups, or sustaining traditional relations of power? The European Journal of Development Research, 20(4), 649-665.

Olivier de Sardan, J.-P. (2005). Anthropology and development: Understanding contemporary social change. London: Zed Books Ltd. 
Olivier de Sardan, J.-P. (2011). Local powers and the co-delivery of public goods in Niger. Ids Bulletin-Institute of Development Studies, 42(2), 32-42.

Olivier de Sardan, J.-P. (2014). The delivery state in Africa. Interface bureaucrats, professional cultures and the bureau- cratic mode of governance. In T. Bierschenk \& J.-P. Olivier de Sardan (Eds.), States at work. Dynamics of African Bureaucracies (pp. 399-426). Leiden: Brill.

Paton, D., \& Johnston, D. (2001). Disasters and communities: Vulnerability, resilience and preparedness. Disaster Prevention Management, 10(4), 270-277.

Resnick, D. (2014a). Strategies of subversion in vertically-divided contexts: Decentralisation and urban service delivery in Senegal. Development Policy Review, 32(Suppl. 1), S61-S80.

Resnick, D. (2014b). Urban governance and service delivery in African Cities: The role of politics and policies. Development Policy Review, 32(2001), S3-S17.

Salem, G. (1992). Crise urbaine et contrôle social à Pikine: bornes-fontaines et clientélisme. Sénégal: la démocratie à Pépreuve. Politique Africaine, 45, 21-38.

Satterthwaite, D. (2011). How can urban centers adapt to climate change with ineffective or unrepresentative local govern- ments? Wiley Interdisciplinary Reviews: Climate Change, 2 (5), 767-776. doi:10.1002/wcc.136

Schaer, C. (2015). Condemned to live with one's feet in water? International Journal of Climate Change Strategies and Management, 7(4), 534-551.

Schaer, C., \& Hahonou, E. K. (2017). The real governance of flood- ing response in peri-urban Senegal: Coproduction, inequity and active citizenship. Progress in Development Studies, 17(2), 38-53.

Senegal Post. (2014). Mal gouvernance: Aucune transparence dans la gestion des inondations (forum civil). Senegal Post. 1.10. Dakar.

Sénégal (République du). (2000). Conseil des ministres, April 13. Dakar.

Sénégal (République du), Agence de développement municipal (ADM). (2011). Projet de Gestion des Eaux Pluviales (PROGEP), Cadre de Gestion environnementale et sociale (CGES), rapport final. Dakar: Author.

Smith, D. J. (2003). Patronage, per diems and the "workshop men- tality": The practice of family planning programs in Southeastern Nigeria. World Development, 31(4), 703-715.

Thiam, M. D. (2011). Le syndrom des inondations au Sénégal. Dakar: Presses universitaires du Sahel.

Thiam, M. D. (2013). Les inondations au Sénégal (2000-2011): une gestion erratique. In M.-C. Diop (Ed.), Sénégal (2000 - 2012) - Les institutions et politiques publiques à Pépreuve d’ une gouvernance libérale (pp. 689-728).

Karthala: CRES.

Thoré, L. (1962). Dagoudane-Pikine. Étude démographique et sociologique. In Bulletin de Pinstitut Francais d Afrique Noire (1st-2nd ed., pp. 155-198). Dakar: IFAN.

UNESCO. (2011). Inondations à Dakar, Document Introductif au Dialogue entre les acteurs. Rapport final. Dakar: Author.

UNISDR. (2013). Consultation nationale sur le cadre d'Action post-2015 pour le réduction des risques de catastrophes. Dakar: Author.

World Bank, \& Global Facility for Disaster Reduction and Recovery (GFDRR). (2011). Vulnerability, risk reduction, and adaptation to climate change - Senegal. Washington, DC: Author.

World Bank, \& Institut Africain de Gestion Urbaine (IAGU). (2009). Preparing to manage natural hazards and climate change riskes in Dakar, Sénégal. Washington, DC: Author.

Yaro, J. A., Teye, J., \& Bawakyillenuo, S. (2015). Local insti- tutions and adaptive capacity to climate change/variability in the northern savannah of Ghana. Climate and Development, 7(3), 235-245. 


\section{Annex 1: Acronyms}

ADM Agence de Développement Municipal

AFDB African Development Bank

AGR Agence Régionale de Développement

ANAMS Agence Nationale de la Météorologie du Sénégal

ANLIB Agence nationale de Lutte contre les Inondations et les Bidonvilles

APIX Agence des Grands Travaux

APR Alliance Pour la République

BNSP Brigade Nationale des Sapeurs Pompiers

BSS Benno Siggil Senegal (united to rebuild Senegal)

CAP Cellule d'Appui Psychologique

CCA Climate Change Adaptation

CNPLI Cellule Nationale de Prévention et de Lutte contre les Inondations

CNPSSLI Commission Nationale de la Prévention, de Supérvision et de Suivi de la Lutte contre les Inondations

CONAGPI Commission Nationale de Gestion Prévisionelle des Inondations

CSPC Commission Supérieure de la Protection Civile

CRD Conseil Régional de Dakar

DPC Direction de la Protection Civile

DRR Disaster Risk Reduction

ECOWAS Economic Community Of West African States

FCFA Franc Communauté Financière Africaine

FDV Fondation Droit à la Ville

GFDRR Global Facility for Disaster Reduction and Recovery

HFRA Hyogo Framework for Action

IAGU Institut African de Gestion Urbaine

MRAZI Ministère de la Restructuration et de l'aménagement des zones d'inondation

ONAS Office National de l'Assainissement du Sénégal

ONPI Office National de Prévention des Inondations.

ORSEC Plan National d'Organisation des Secours

PAQPUD Programme d'assainissement des quartiers péri urbains de Dakar

PCLSLB Programme de construction des logements sociaux et de lutte contre les banlieues

PDDEP Plan Directeur de Drainage des Eaux Pluviales

PDGI Plan Décennal de Gestion des Inondations

PDNA Post Disaster Needs Assessment

PDS Parti Démocratique Sénégalais

PELT Programme Eau à Long Terme

PEPAM Programme d'eau potable et d'assainissement du millénaire Programme

PIS Pikine Irrégulier Sud project

PNRRMC: Plateforme Nationale pour la Réduction des Risques Majeurs de Catastrophe

PRQS: Politique de Restructuration et de Régularisation des quartiers spontanés

PROGEP: Projet de Gestion des Eaux Pluviales et d'Adaptation au Changement Climatique

UEMOA: Union Economique et Monétaire Ouest Africaine

UNISDR: United Nations Office for Disaster Risk Reduction 


\section{Annex 2: Main actors involved in urban flood management in Senegal}

\begin{tabular}{|c|c|c|c|}
\hline \multicolumn{2}{|l|}{ Sector } & \multirow{2}{*}{$\begin{array}{l}\text { Area of responsibility } \\
\text { Coordination of Disaster Risk Reduction (DRR) } \\
\text { activities } \\
\text { Advise Ministry of Interior on DRR issues }\end{array}$} & \multirow{2}{*}{$\begin{array}{l}\text { Year of } \\
\text { creation } \\
1999\end{array}$} \\
\hline $\begin{array}{l}\text { Ministry of } \\
\text { Interior }\end{array}$ & $\begin{array}{l}\text { High Commission of Civil } \\
\text { Protection (CSPC) }\end{array}$ & & \\
\hline & $\begin{array}{l}\text { Directorate of Civil } \\
\text { Protection (DPC) }\end{array}$ & $\begin{array}{l}\text { Coordination of National Relief Organisation } \\
\text { Plan (Plan ORSEC) }\end{array}$ & 1999 \\
\hline & $\begin{array}{l}\text { National Brigade of } \\
\text { Firefighters (BNSP) }\end{array}$ & $\begin{array}{l}\text { Organisation of Emergency Relief \& } \\
\text { implementation of ORSEC plan }\end{array}$ & 1964 \\
\hline & $\begin{array}{l}\text { Directorate for National } \\
\text { Police }\end{array}$ & $\begin{array}{l}\text { Traffic, information and security management in } \\
\text { the context of flooding }\end{array}$ & 2009 \\
\hline \multirow[t]{3}{*}{$\begin{array}{l}\text { Ministry of } \\
\text { Health }\end{array}$} & $\begin{array}{l}\text { Directorate of Medical } \\
\text { Prevention (DPM) }\end{array}$ & Medical prevention, community health & 2005-2009 \\
\hline & $\begin{array}{l}\text { Directorate of Public Hygiene } \\
(\mathrm{DHP})\end{array}$ & $\begin{array}{l}\text { Implementation of hygiene and public health } \\
\text { policy }\end{array}$ & $1996-2004$ \\
\hline & $\begin{array}{l}\text { Cellule d'Appui } \\
\text { Psychologique (CAP) }\end{array}$ & Psychological assistance to flood victims & 2005 \\
\hline \multirow{2}{*}{$\begin{array}{l}\text { Ministry of } \\
\text { Urban } \\
\text { Development } \\
\text { and Housing } \\
\text { (MUH) }\end{array}$} & \multicolumn{2}{|c|}{$\begin{array}{l}\text { MUH's urban planning missions and land use control are at the heart of flood } \\
\text { management: construction norms, use of land, urban planning and development. } \\
\text { (Décret } n^{\circ} 2004-84 \text { du } 23 \text { janvier 2004) }\end{array}$} & \multirow[b]{2}{*}{2006} \\
\hline & Plan Jaxaay Directorate & $\begin{array}{l}\text { Construction of water retention basins } \\
\text { Housing construction for flood victims }\end{array}$ & \\
\hline $\begin{array}{l}\text { Ministry of } \\
\text { Economy and } \\
\text { Finance }\end{array}$ & $\begin{array}{ll}\text { Municipal } & \text { Development } \\
\text { Agency }(\mathrm{ADM}) & \end{array}$ & $\begin{array}{l}\text { Support decentralisation process } \\
\text { Funds an emergency action plan for optimizing } \\
\text { pumping of storm water drainage (2010) } \\
\text { Implements PROGEP }\end{array}$ & 2009 \\
\hline \multirow[t]{4}{*}{$\begin{array}{l}\text { Ministry of } \\
\text { Water and } \\
\text { Sanitation }\end{array}$} & $\begin{array}{l}\text { National office for sanitation } \\
\text { (ONAS) }\end{array}$ & $\begin{array}{l}\text { Implementation of construction projects, } \\
\text { rehabilitation and maintenance of drainage } \\
\text { systems }\end{array}$ & 1996 \\
\hline & Sanitation department & $\begin{array}{l}\text { Responsable for the Directory Plan for rain water } \\
\text { Drainage (PDDEP) }\end{array}$ & 2011 \\
\hline & $\begin{array}{l}\text { National Agency against } \\
\text { Floods and Slums (ANLIB) }\end{array}$ & $\begin{array}{l}\text { Housing restructuring and control of new } \\
\text { settlements }\end{array}$ & $\begin{array}{l}\text { April } 2006 \\
\text { to Mai } 2006\end{array}$ \\
\hline & $\begin{array}{l}\text { Directorate for Water } \\
\text { Resource Management and } \\
\text { Planning (DGPRE) }\end{array}$ & $\begin{array}{l}\text { Studies on water resources, inventory, planning and } \\
\text { water ressource management }\end{array}$ & 2004 \\
\hline \multirow{2}{*}{$\begin{array}{l}\text { Ministry in } \\
\text { Charge of } \\
\text { Restructuring } \\
\text { and } \\
\text { Managing } \\
\text { Flood Zones } \\
\text { (MAZRI) }\end{array}$} & $\begin{array}{l}\text { National Flood Prevention } \\
\text { Office (ONPI) }\end{array}$ & \multirow{2}{*}{$\begin{array}{l}\text { Responsible for construction and social housing } \\
\text { program to prevent slums (PCLSLB) } \\
\text { Initiates PCDI } \\
\text { Coordinates the management of storm water drainage } \\
\text { systems }\end{array}$} & \multirow[t]{2}{*}{ 2012-2014 } \\
\hline & $\begin{array}{l}\text { National Flood Committee } \\
\text { (under Ministry of housing } \\
\text { and construction then } \\
\text { Ministry of Water and } \\
\text { sanitation in 2012, then } \\
\text { MRAZI in 2013) }\end{array}$ & & \\
\hline
\end{tabular}

Table 2: Ministries involved in urban flood management in Senegal 


\begin{tabular}{|c|c|c|c|}
\hline \multicolumn{2}{|l|}{ Institution } & \multirow{2}{*}{$\begin{array}{l}\text { Area of responsibility } \\
\text { Large scale infrastructure construction (highway) } \\
\text { Implements part of the rainwater drainage component } \\
\text { of PROGEP }\end{array}$} & \multirow{2}{*}{$\begin{array}{l}\text { Year } \\
2007\end{array}$} \\
\hline $\begin{array}{l}\text { Semi- public, } \\
\text { and private } \\
\text { organisations }\end{array}$ & $\begin{array}{l}\text { National Agency for Investment Promotion } \\
\text { of large scale construction (APIX) }\end{array}$ & & \\
\hline & 'Droit à la Ville' foundation (FDV) & $\begin{array}{l}\text { Restructuring plans, regularisation fonciere des } \\
\text { quartiers irréguliers }\end{array}$ & 1994 \\
\hline & $\begin{array}{l}\text { National Agency of Meteorology of Senegal } \\
\text { (ANAMS ) }\end{array}$ & Implementation of government meteorology policy & 2002 \\
\hline & $\begin{array}{l}\text { National Agency of Statistics and } \\
\text { Demography (ANSD) }\end{array}$ & $\begin{array}{l}\text { Collection of statistical data ; economic, socio- } \\
\text { economic studies, }\end{array}$ & 2005 \\
\hline & $\begin{array}{l}\text { Société Nationale des Télécommunications } \\
\text { du Senegal (SONATEL) }\end{array}$ & Telecommunications, involved in ORSEC plan & 1996 \\
\hline & Cleaning and Hygiene Agency (APROSEN) & $\begin{array}{l}\text { Public Cleansing Activities, collection, transport, } \\
\text { processing / recycling and disposal of solid waste }\end{array}$ & 2005 \\
\hline & $\begin{array}{l}\text { National office for low-cost housing } \\
\text { (ONHLM) }\end{array}$ & Social Housing for flood victims & $\begin{array}{l}2006- \\
2013\end{array}$ \\
\hline & SONES \& Sénégalaise des Eaux (SDE) & Water utilities & 1996 \\
\hline & AGEROUTE & Road works utility & 2010 \\
\hline & Cap Vert Real Estate Company (SICAP) & $\begin{array}{l}\text { Housing construction and planning of development } \\
\text { areas to support flood victims. }\end{array}$ & 2007 \\
\hline & $\begin{array}{l}\text { National Society of Electricity in Senegal } \\
\text { (SENELEC) }\end{array}$ & Electricity access & 1998 \\
\hline & CETUD & Urban transportation & 1997 \\
\hline \multirow{11}{*}{$\begin{array}{l}\text { Bilateral and } \\
\text { multilateral } \\
\text { organisations } \\
\text { and NGOs }\end{array}$} & World Bank & $\begin{array}{l}\text { Financing of major flood management programmes, } \\
\text { plan and assessment reports (PDNA, PROGEP, } 10 \\
\text { year Plan) }\end{array}$ & $\begin{array}{l}2010- \\
2015\end{array}$ \\
\hline & $\begin{array}{l}\text { The European Commission with support } \\
\text { from Italy, Luxembourg, France, Sweden, } \\
\text { Germany }\end{array}$ & $\begin{array}{l}\text { Humanitarian aid through various United Nations } \\
\text { system offices }\end{array}$ & 2009 \\
\hline & Islamic Investment Bank & $\begin{array}{l}\text { Support of emergency operations by providing } \\
\text { assistance to populations }\end{array}$ & 2009 \\
\hline & $\begin{array}{l}\text { United Nations organisations (WFP, } \\
\text { UNICEF, UNFPA, WHO, UNDP, OCHA) }\end{array}$ & $\begin{array}{l}\text { Support in achieving the MDGs and relief and } \\
\text { recovery support to flood victims }\end{array}$ & $\begin{array}{l}2009- \\
2015\end{array}$ \\
\hline & $\begin{array}{l}\text { International Federation of Red Cross and } \\
\text { Red Crescent Societies (IFRC) }\end{array}$ & $\begin{array}{l}\text { Coordinate and direct relief operations during natural } \\
\text { disasters - Responding to emergencies }\end{array}$ & 1960 \\
\hline & Adaptation Fund & $\begin{array}{l}\text { Financial support for adaptation projects and } \\
\text { programs on climate change }\end{array}$ & 2011 \\
\hline & Red Cross & $\begin{array}{l}\text { Training of volunteers, capacity building and } \\
\text { assessment of vulnerability and capacity. }\end{array}$ & $\begin{array}{l}\text { since } \\
1960\end{array}$ \\
\hline & Germany & $\begin{array}{l}\text { support through the International Federation of Red } \\
\text { Cross Societies and Red Crescent Societies (IFRC) }\end{array}$ & $\begin{array}{l}2009- \\
2011\end{array}$ \\
\hline & UK & $\begin{array}{l}\text { Building Resilience and adaptation to climate extremes } \\
\text { and disasters (BRACED) programme }\end{array}$ & 2014 \\
\hline & $\begin{array}{l}\text { NGOs: International Federation of Red } \\
\text { Cross and Red Crescent societies (IFRC), } \\
\text { SOS Children Village, Christian Relief } \\
\text { Services' (CRS) Islamic relief France, ATD } \\
\text { Quart Monde, World vision Senegal, } \\
\text { CARITAS, OXFAM GB, EVE, IAGU, } \\
\text { ENDA, ACI, IUCN, GREEN Senegal, } \\
\text { Medicos del Mundos, Plan Sénégal, Secours } \\
\text { Islamique Francais, Terre Nouvelle Suisse, } \\
\text { Water Aid, World Vision }\end{array}$ & $\begin{array}{l}\text { Flood mitigation, relief and recovery support, capacity } \\
\text { building, research }\end{array}$ & \\
\hline & $\begin{array}{l}\text { NGO Council in support of development } \\
\text { (CONGAD) }\end{array}$ & $\begin{array}{l}\text { Support actors to integrated disaster risk reduction and } \\
\text { management in Local Development }\end{array}$ & 2000 \\
\hline
\end{tabular}

Table 3: Main organisations involved in urban flood management in Senegal 